\title{
Study of Antimicrobial Resistance Pattern of Escherichia coli and Klebsiella Strains and Multivariate Analysis for Water Quality Assessment of Tigris River, Baghdad, Iraq
}

\author{
Ban O. Abdulsattar*, Jwan O. Abdulsattar**, Khetam H. Rasool*, Abdul-Rahman A. Abdulhussein* and \\ Mohammad H. Abbas* \\ *Department of Biology, College of Science, Mustansisiyah University, Baghdad, Iraq \\ **Department of Chemistry, College of Science, Mustansisiyah University, Baghdad, Iraq \\ $\dagger$ Corresponding author: Jwan O. Abdulsattar; abdulsattarjwan@yahoo.com
}

Nat. Env. \& Poll. Tech. Website: www.neptjournal.com

Received: 02-08-2019

Revised: 29-09-2019

Accepted: 07-11-2019

Key Words:

Antibiotics resistant bacteria Heavy metals

Tigris River

Water quality assessment

\begin{abstract}
The present study aims to assess the pollutant impact from everyday untreated or partially treated industrial wastes, wastewater treatment plants and Baghdad Medical City wastewater discharge into Tigris River, Baghdad, Iraq. Water samples were collected from seven locations of the Tigris River near Baghdad Medical City in November 2018. Morphological characteristics and biochemical methods were used to characterize Escherichia coli and Klebsiella isolates revealing that the Tigris River accumulate different amounts of antibiotic-resistant E. coli and Klebsiella sp. isolates and that pattern of resistance is different in each site. E. coli was the predominant bacterial contaminant at site 1 which is near sewage of several hospitals in Baghdad Medical City. The influence of different water quality parameters (total dissolved solids, electric conductivity, alkalinity, turbidity, total hardness, calcium, magnesium, sodium, potassium, phosphate ion, nitrate, sulphate, chloride) and heavy metals (Cd, Zn, $\mathrm{Co}, \mathrm{Cu}$, and $\mathrm{Ni}$ ) were investigated at bacterial contaminated site 1. Besides, physiological parameters $(\mathrm{pH}$ value and temperature) were applied. The results revealed that these parameters were within Iraqi standards levels with a slight increase in $\mathrm{pH}$ and temperature at site 1.
\end{abstract}

\section{INTRODUCTION}

Historically, the Tigris and the Euphrates are the two most significant rivers in Iraq. The Tigris River gains great importance as it is considered the main source of water for Baghdad city, which enters the capital city of Baghdad from the north and exit from the south dividing Baghdad city into the right (Karkh) and left (Rusafa) sections (Alobaidy et al. 2010). For several years the Iraqi rivers were facing problems such as the huge number of dams built in the upstream by Turkey and Iran (Al-Ansari 2013), the floods caused by rains and the discharge of wastewater from the residential and commercial establishments along Tigris River. A little knowledge is currently available on to what extent the biological and chemical pollution affects the Tigris River ecosystems in Baghdad city. Due to the anthropogenic activities, the ecosystems for plants and living organisms are threatened by toxic pollutants, which are passed directly from factories and hospitals into the river without any real treatments (Gadzalla-Kopciuch 2004).

One of the major pollutants is antibiotics and antibiotic-resistant bacteria. The heavy use and abuse of antibiotics have resulted in multi-resistant bacteria (Icgen \& Yilmaz
2014, Lv et al. 2015, Xu et al. 2017). Although a complete picture of the ecology of the antibiotic-resistant bacteria is still missing, the growing use of antibiotics for medical treatments and in animal production as growth promoters has increased a selective pressure in bacterial populations and the development of antibiotic-resistant bacteria (Titilawo et al. 2015, Zarfel et al. 2013, Zhang et al. 2015). There is a continuous release of antibiotics into the environment from different human activities such as wastewater treatment plants and hospitals effluents, combined sewer overflows, processing plant effluents and agricultural waste (Davies \& Davies 2010, Michael et al. 2013). The presence of antibiotics in the Tigris River draws the attention of the researchers due to the risk of spreading antibiotic resistance determinants through microbial communities. The wastewater carries antibiotics and their metabolites, which is excreted with urine and faeces (Harnisz 2013, Le Corre et al. 2012, Leung et al. 2012). In addition, there is a direct inflow of resistant bacteria to the wastewater, especially from the hospital wastewater (Chagas et al. 2011, Korzeniewska 2011). These two major sources of contaminant are released into rivers and lakes directly or from treated sewage. Also, several factories and 
hospitals drain their wastewater into the river. As a result, there are many direct and indirect sources which are responsible for the contamination of the Tigris River in Baghdad city (Ibrahim \& Asmaa 2017).

Water quality tests stand as an informatics platform to provide valuable data that lead to maintaining a healthy aquatic ecosystem. Some aquatic ecosystems can resist large and different changes in water quality without any detectable effects on the ecosystem, however other ecosystems are more sensitive to small changes in the physical and chemical parameters which can lead to degradation of the ecosystem and affect biological diversity. The changes of physical and chemical water quality are a result of human influences and usually gradual and undetectable due to the invisible adaptations of aquatic ecosystems unless a dramatic shift in ecosystem condition occurs (Stark Jr et al. 2000). The physical and chemical characteristics of a water sample are compared with the World Health Organization (WHO) guidelines or standards to determine water quality. One of the problems is the lack of expert study and regular monitoring of the water quality of most rivers (Robertson et al. 2006, Wickham et al. 2005). It is important to perform river water quality assessment to evaluate the water quality and to detect pollution sources (Sin et al. 2001, Yuan et al. 2011). The rapid population growth and intensive domestic activities, in addition to expanding industrial and agricultural production, which has resulted in the release of large quantities of toxic chemicals, especially heavy metals into rivers worldwide (Srebotnjak et al. 2012, Su et al. 2013). However, toxic metals are not considered in many studies like the major ion chemistry of rivers. Heavy metals may undergo many changes in their speciation due to dissolution, precipitation, sorption, and complexation phenomena during their transport in rivers (Abdel-Ghani \& Elchaghaby 2007, Akcay et al. 2003) and this will affect their behaviour and bioavailability (Nicolau et al. 2006, Nouri et al. 2011). A study suggested that the downstream of Tigris River is more seriously polluted by heavy metals than the upstream and midstream sites in Baghdad city (Obaidy 2014). While another study reported that some heavy metals $(\mathrm{Cu}, \mathrm{Hg}, \mathrm{Pb}$, and $\mathrm{Zn}$ ) were within the normal limit except $\mathrm{Cd}$ ion, which was slightly elevated in Tigris River water samples in Baghdad city (Ibrahim \& Asmaa 2017). This work aims to study the profile and prevalence of antibiotic-resistant bacteria in the environment of Tigris River in Baghdad city near Baghdad Medical City and also measures the physical and chemical parameters in Tigris River to understand their effect on the aquatic ecosystem and biological diversity and to investigate whether Tigris River water has been contaminated with heavy metals or not.

\section{MATERIALS AND METHODS}

Study sites and collection of water samples: Total 7 river water samples were collected from different locations of the Tigris River in Baghdad city, Iraq in November 2018. Samples were collected from $50 \mathrm{~cm}$ below the surface of the Tigris River in $100 \mathrm{~mL}$ sterile bottles and $1 \mathrm{~m}$ from the edge. All samples were immediately placed on ice and transported back to the laboratory on the same day of collection for further processing.

Physicochemical parameters: Physicochemical parameters including temperature $\left({ }^{\circ} \mathrm{C}\right)$ and $\mathrm{pH}$ were determined for each Tigris River sample site and recorded using standard methods. This was done with three replication per sample.

Isolation and characterization of bacteria: After the removal of larger particulates by centrifugation at $5000 \mathrm{rpm}$ for 10 minutes, $100 \mu \mathrm{L}$ and $50 \mu \mathrm{L}$ from each supernatant were spread on a selective media (MacConkey agar and EMB agar) plates. After 24 hours of incubation at $37^{\circ} \mathrm{C}$, the bacterial colonies with distinct colony morphology were selected and analysed for morphological and biochemical characteristics by IMVIC analysis test.

Antimicrobial susceptibility testing: The antibiotic susceptibility test was done by disc diffusion method. All isolates were cultured on MacConkey agar and incubated for 18 hours at $37^{\circ} \mathrm{C}$. In the next day, two to three colonies of these organisms were emulsified with normal saline to adjust the inoculum density equal to that of 0.5 MacFarland turbidity standards. Using a cotton swab, each bacterial isolate was spread on Mueller-Hinton agar and left for 10 min at room temperature, and 8 different antibiotics (Amikacin $(\mathrm{AK}-30 \mu \mathrm{g})$, gentamicin $(\mathrm{GM}-10 \mu \mathrm{g})$, Ciprofloxacin (CIP-10 $\mu \mathrm{g}$ ), trimethoprim (TMP-10 $\mu \mathrm{g}$ ), Amoxicillin (Ax$25 \mu \mathrm{g}$ ), imipenem (IPM-10 $\mu \mathrm{g}$ ), Cefotaxime (CTX-30 $\mu \mathrm{g}$ ), Azithromycin (AZM-15 $\mu \mathrm{g}$ ) discs were placed on the top of the agar and all plates were incubated at $37^{\circ} \mathrm{C}$ for $24 \mathrm{hrs}$. After the incubation period, the inhibition zone diameters around the discs were measured using a ruler and then classified according to the standardized table supplied by CLSI guidelines (Wayne 2014).

Chemical analysis: Chemical analysis including the total dissolved solids (TDS), electric conductivity (E.C.), alkalinity (ALK), turbidity (tur) and total hardness (TH), and the major ions $\left(\mathrm{Ca}^{2+}\right)$, magnesium $\left(\mathrm{Mg}^{2+}\right)$, sodium $\left(\mathrm{Na}^{+}\right)$, potassium, $\left(\mathrm{K}^{+}\right)$, phosphate ion $\left(\mathrm{PO}_{4}^{-3}\right)$, nitrate $\left(\mathrm{NO}_{3}{ }^{-}\right)$, sulphate $\left(\mathrm{SO}_{4}{ }^{2-}\right)$ and chloride $\left(\mathrm{Cl}^{-}\right)$were measured using different methods as listed in Table 1.

Heavy metals analysis: Heavy metals including cobalt, zinc, copper, cadmium, and nickel were determined by 
Table 1: Methods used for measuring chemical parameters.

\begin{tabular}{|ll|}
\hline Test & Method \\
\hline Total Dissolved Solids (TDS) & Gravimetric method (Drying at $103-105^{\circ} \mathrm{C}$ ) \\
Electric conductivity (E.C) & Electric conductivity meter \\
Alkalinity (ALK) & pH meter \\
Turbidity (tur) & Nephelometer \\
$\mathrm{Ca}^{2+}$ & EDTA titration method \\
$\mathrm{Mg}^{2+}$ & Atomic absorption spectrophotometer \\
$\mathrm{Na}^{+}$ & Atomic absorption spectrophotometer \\
$\mathrm{K}^{+}$ & Atomic absorption spectrophotometer \\
$\mathrm{PO}_{4}^{-3}$ & Atomic absorption spectrophotometer \\
$\mathrm{NO}_{3}^{-}$ & Spectrophotometer \\
$\mathrm{SO}_{4}^{2-}$ & Spectrophotometer \\
$\mathrm{Cl}^{-}$ & Turbidity metric method \\
\hline
\end{tabular}

atomic absorption spectrophotometer for water sample in triplicate per sample.

\section{RESULTS AND DISCUSSION}

\section{Description of the Study Area}

Water samples were taken from 7 sites from Tigris River near the Medical city; Baghdad, Iraq. The total sites distance was
1.975 meters; site 1 was the municipal sewage of Baghdad Medical city and samples were taken from both side of Tigris River as can be seen from Fig 1.

\section{Isolation of E. coli and Klebsiella}

The occurrence of E. coli and Klebsiella in river water samples varied in different sites. The highest number of bacteria was located at site 1 , which indicated that the river water

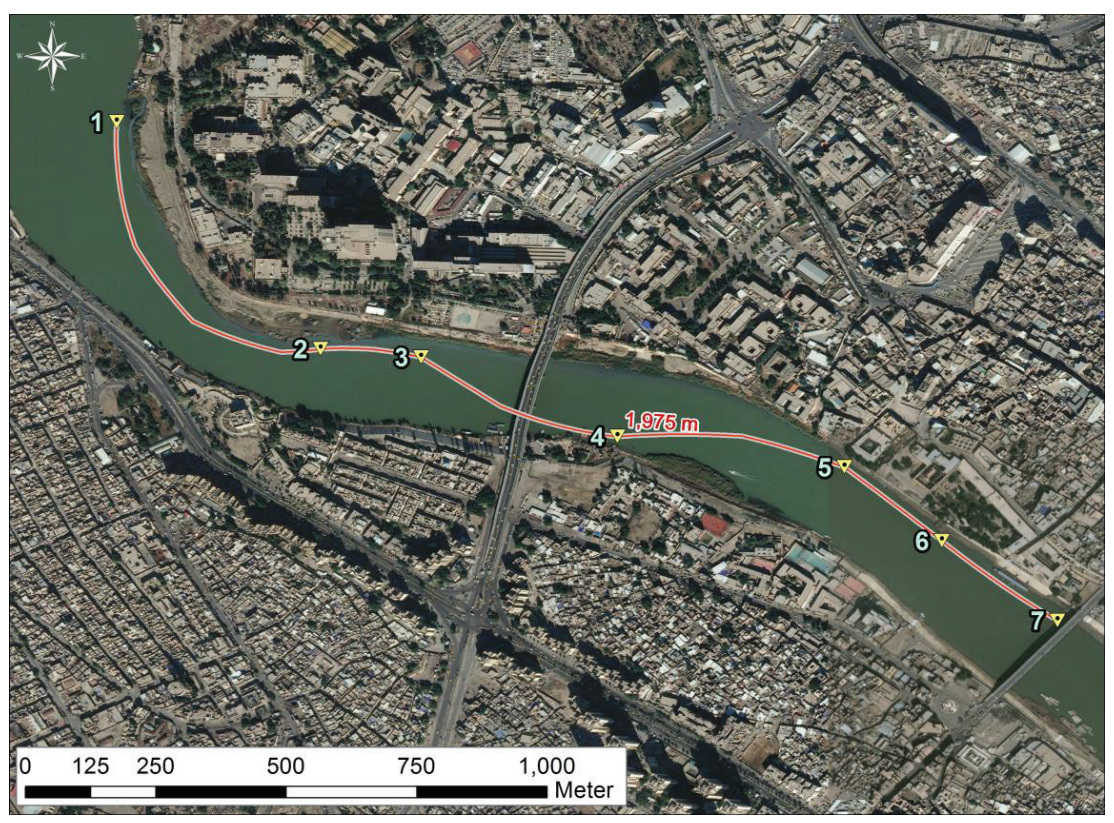

Fig. 1: Description of the study sites. S1: Baghdad Medical city municipal sewage, S2: Medical city hospitals, S3: Medical city hospitals, S4: Residential area, S5: Qishla building, S6: Qishla hour, and S7: Mosque Wazzar. 
was severely polluted and suitable for the rapid growth of bacteria (Fig. 2).

The number of E. coli and Klebsiella at site 1 was significantly higher than the average level of all sampling sites. One possible explanation for this high bacteria abundance was that the water sample at site 1 was collected from the sewage of several hospitals. Site 7 showed a lower number of bacterial isolates. Therefore, it could be speculated that we can see low numbers of bacterial isolates as we go far from sources for river water pollutions.

\section{Profile of Multi-Drug Resistant E. coli and Klebsiella Isolates from Tigris River}

A total of 9 confirmed E. coli and Klebsiella isolates were profiled for their probable phenotypic resistance to 8 different antimicrobials. All E. coli isolates showed a high level of resistance against amoxicillin as shown in Fig. 3. Varied resistances for other antibiotics were recorded as follows: high levels of resistance equally observed against Gentamicin and Azithromycin. The $E$. coli isolate at $\mathrm{S} 1$ was more resistant to different antibiotics than E. coli isolate at S7. Conversely, all the E. coli isolates were susceptible to Ciprofloxacin and Imipenem. Although wastewater treatment processes reduced bacterial numbers in the sewage and attributed to a partial reduction of microorganism number due to the dilution of treated sewage in river water. The bacterial isolates showed resistance to different antibiotics, which indicates high contamination in the S1 site with antibiotic-resistant bacteria discharged from the sewage of Baghdad medical city hospitals. The pollution of river water is influenced by population density and economic activities, especially sewage effluent. Even with the presence of several water treatment

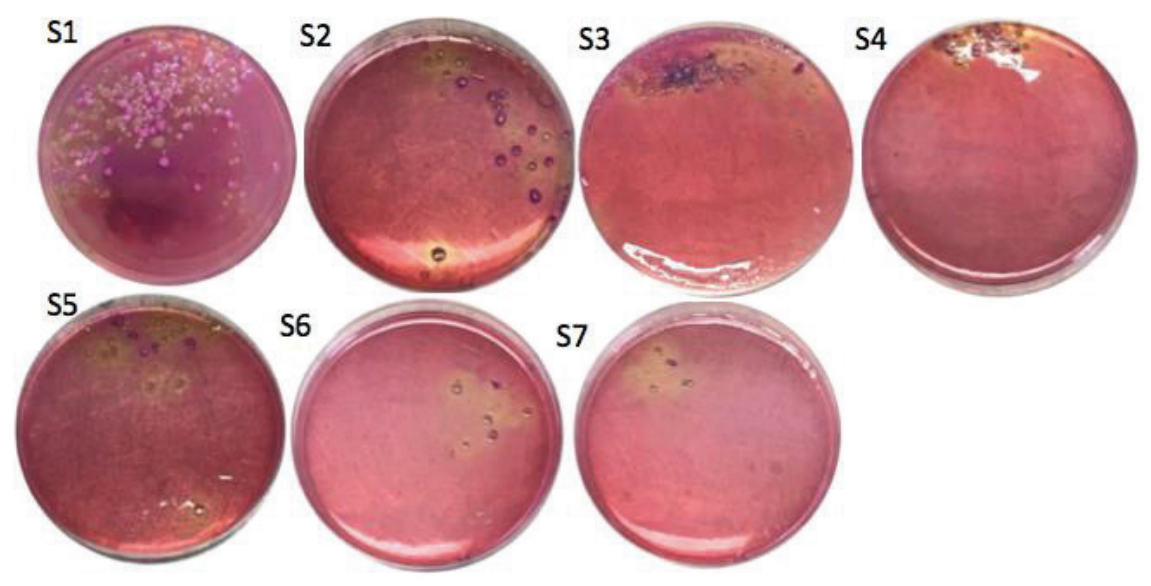

Fig. 2: Heterogenic diversity of the bacteria from Tigris River water samples.

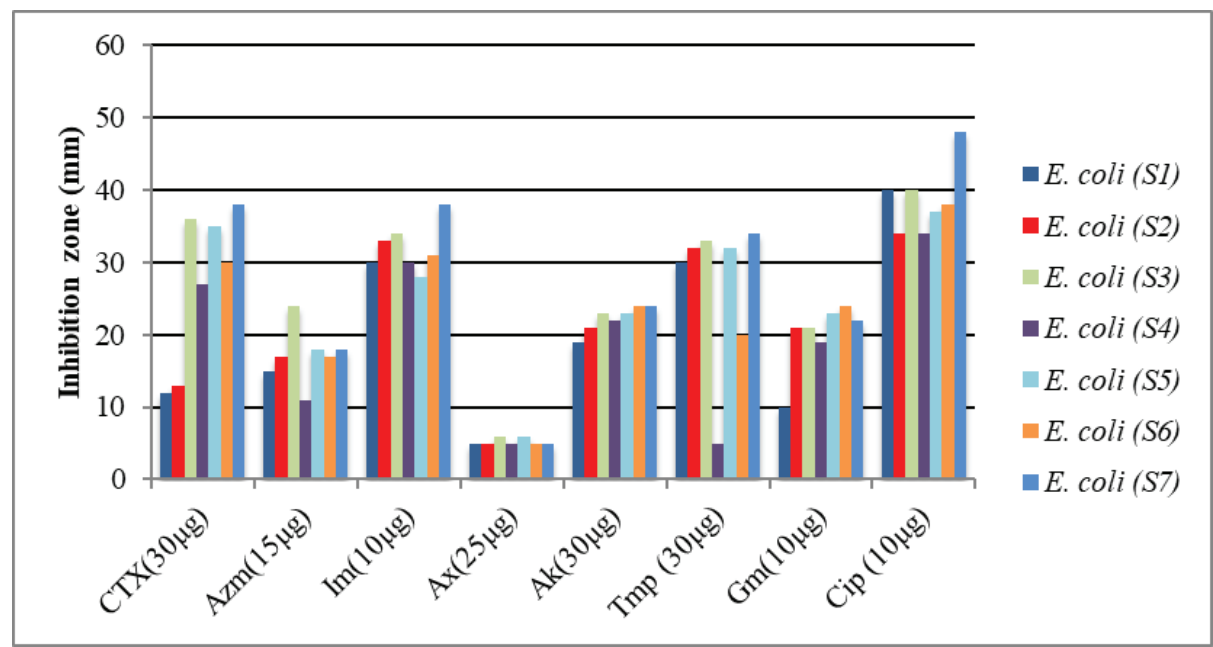

Fig. 3: Antimicrobial resistance of E. coli isolated from a river sample. 
plants located within Baghdad city, water samples from these plants were contaminated with faecal coliform (Hassan \& Mahmood 2018). The presence of coliforms in drinking water is an indicator of water contamination with bacteria or viruses that occur in a faecal matter (Bain et al. 2014). A study showed that upstream of the Tigris River in Baghdad city has the highest total coliform presence (AL-Dulaimi \& Younes 2017). The large population, extensive industrial activities and sewage of several hospitals may attribute for contamination of Tigris River with coliform and especially E. coli. The comparison between Klebsiella isolates was not considered since Klebsiella isolates were detected only in two sites from total of seven sites.

The comparison between E. coli and Klebsiella isolates in $\mathrm{S} 1$ and S7 cited in Fig. 4 revealed that E. coli and Klebsiella isolates at both sites were resistant to amoxicillin and $E$. coli isolates at S1 and S7 were more resistant to different antibiotics than Klebsiella isolates which were sensitive to ciprofloxacin, gentamicin, and trimethoprim. This result may be attributed to the E. coli resistance characteristics, which indicates that multilateral exchange of genetic material between bacteria of both anthropogenic and en- vironmental origins is currently occurring and presents a phenomenon of growing importance or river water sample collected near S1 site carried faecal coliforms bacteria from untreated hospital sewage coming from all units of the hospitals, including laboratories, rehabilitation, dialysis, hospitalization, and surgery units, clinics, maternity, laundry, and the cafeteria.

The difference between E. coli and Klebsiella isolates from $\mathrm{S} 1$ showed that $E$. coli are more resistant to selected antibiotics than Klebsiella. The obtained result indicates that E. coli heavily contaminates the Tigris River. The discharged sewage may also contain antibiotics used as a treatment for patients in these hospitals. A study by Mahmood et al. (2019) confirmed the contamination of water samples in Baghdad city with different antibiotics including fluoroquinolones and B-lactams. The highest antibiotic concentration recorded was ciprofloxacin in the Al-Wihda plant, while amoxicillin was not detected in the same site. Despite the treatment of the municipal sewage, river water may be a good reservoir for antibiotic-resistant microorganisms and plasmid-mediated antibiotic resistance genes. This may pose a public health risk, which needs future evaluation and control.

Table 2: Temperature and $\mathrm{pH}$ parameters of the studied area.

\begin{tabular}{|llllllll|}
\hline Site & S1 & S2 & S3 & S4 & S5 & S6 \\
\hline Temperature & 22 & 18.1 & 18.3 & 18 & 18.3 & 18 & 78.5 \\
pH & 8 & 7 & 7 & 7.5 & 7 & 7 \\
\hline
\end{tabular}

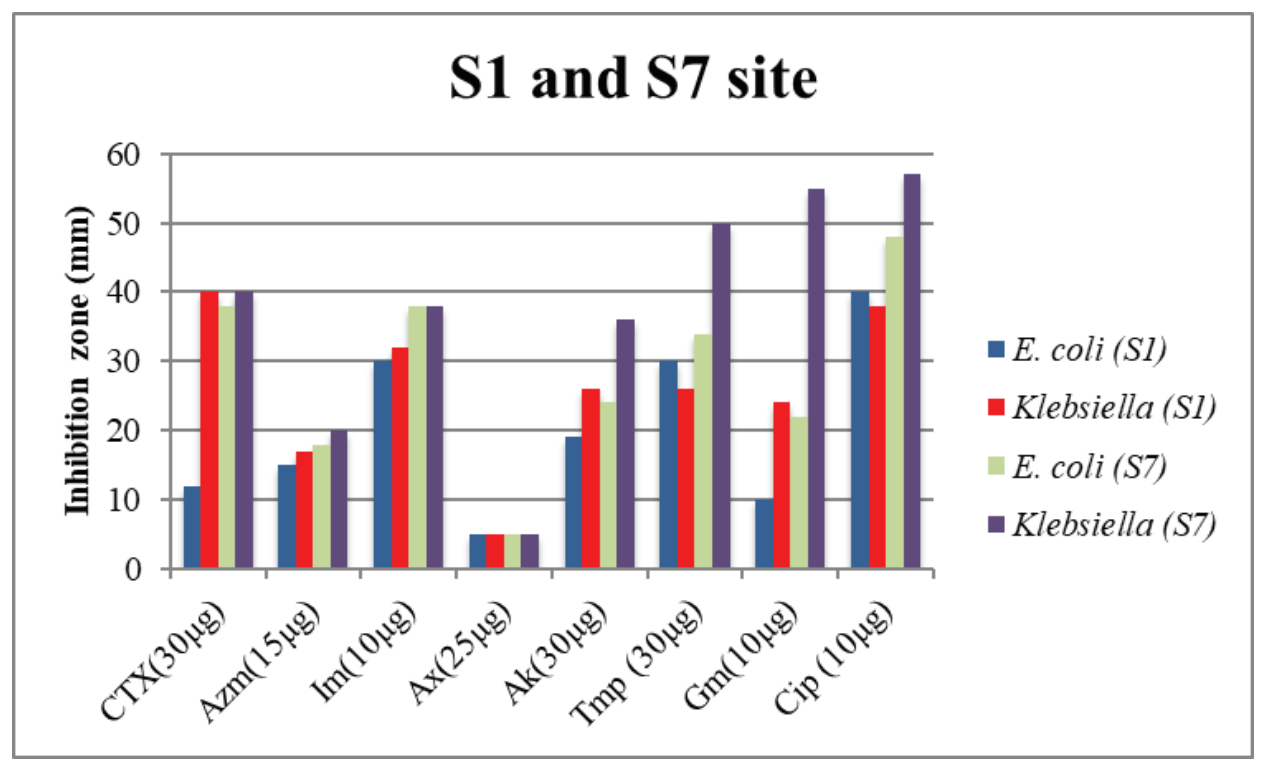

Fig. 4: Antimicrobial resistance of E. coli and Klebsiella isolated from S1 and S7 river sample. 


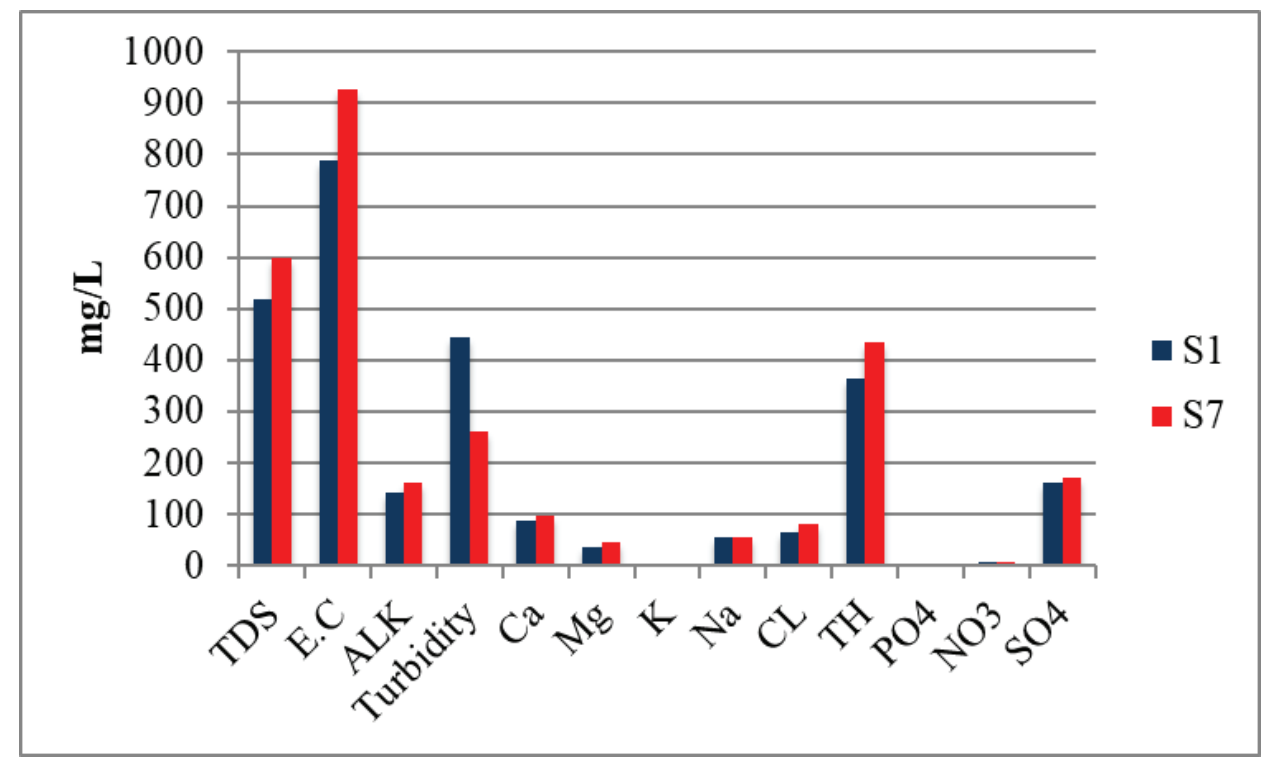

Fig. 5: The concentration of major ions and some environmental parameters in the Tigris Rivers, Baghdad city at site 1 and 7.

\section{Physicochemical Characteristics}

The water temperature is an important factor in water quality and the distribution of organisms in an aquatic ecosystem in addition to its role in many metabolisms and other transformations in a water body (Smith 2004). The physicochemical parameters of river water samples are presented in Table 2. The temperature ranged from $18-18.5^{\circ} \mathrm{C}$ from site 2 to site 7 . The highest temperature was noticed at site $1\left(22^{\circ} \mathrm{C}\right)$, which is near Medical City hospitals. Minor differences in $\mathrm{pH}$ were observed between sampling sites. The $\mathrm{pH}$ values ranged from 7 to 8, indicating that the Tigris River in Baghdad city is alkaline $(\mathrm{pH}>7)$. The highest $\mathrm{pH}$ was also recorded at site 1. There are no significant differences in temperature and $\mathrm{pH}$ between sampling sites. The Iraqi rivers are characterized by high buffer capacity which explains high pH (Hassan 2004, Abbas 2017).

\section{Environmental Parameters and Metal Concentration}

The results in Fig. 5 show different environmental parameters and metal concentrations in water samples of the Tigris River that revealed the difference in turbidity only while there was no significant variation for the other parameters between site 1 and site 7 in this study.

Anthropogenic activity has a great impact on the Tigris River ecosystem. A recent study revealed that middle of Tigris River in Baghdad city (Al-Sarrafia Bridge and Al-Shuhada Bridge) is heavily polluted than upstream of Tigris River (Al-Ani et al. 2019). This study recorded data from February
2017 to February 2018, which agree with our obtained data in November 2018. Due to the increase in rainfall proportion and high water levels in winter in addition to domestic wastes, the turbidity levels increases in river water (Gangwar et al. 2012, Al-Obaidi 2009). In the aquatic ecosystems, electrical conductivity is considered as a good indicator to evaluate total dissolved solids in river water and water purity. The obtained data showed that conductivity in site 1 and site 7 is less than $(1500 \mu \mathrm{S} / \mathrm{cm})$ which is the Iraqi permissible limits for electrical conductivity (Hassan \& Mahmood 2018).

The concentration for each heavy metal was measured and $\mathrm{Co}, \mathrm{Zn}, \mathrm{Cu}, \mathrm{Cd}$ and $\mathrm{Ni}$ were Nil, 0.007, 0.011, Nil and $0.059 \mathrm{ppm}$, respectively which indicates that site 1 was not contaminated with heavy metals. The result of heavy metal concentrations in site 1 gives an insight view of Tigris River sample safety at site 1 . A study suggested that the site, which is located at the downstream of Tigris River is more seriously polluted by heavy metals than the upstream and midstream sites in Baghdad city (Obaidy et al. 2014).

\section{CONCLUSION}

The contamination of the Tigris River in Baghdad city with antibiotic-resistant bacteria is a threat to human health and the river ecosystem. The cause of resistance, or mode of transmission of the antibiotic-resistant gene between pathogenic and environmental bacteria, is unknown. This study indicates that Tigris River in Baghdad city near Baghdad Medical City is a major source of antibiotic-resistant $E$. coli. A vast 
quantity of antibiotic-resistant bacteria is discharged to the aquatic ecosystem with hospital sewage. Urgent measures are needed to minimize the effects of releasing wastewaters into water resources. One of the solutions that could minimize the spreading of antibiotic-resistant bacteria to the environment is the preliminary disinfection of hospital sewage before its inflow into the sewage system or Tigris River. This study can provide a platform for defying the currently most popular antibiotic options for human therapy by studying the resistance characteristics of the isolates described in this study. It also appears that drug-resistant E. coli is widely distributed in all the rivers sampling sites. Monitoring physiological and chemical parameters in the Tigris River is needed for proper management. Determination of the water quality is essential and comparing the physical and chemical characteristics of a water sample with water quality guidelines. These parameters should be usually at acceptable levels either to humans or aquatic organisms. This study also confers that site 1 is not contaminated with heavy metals.

\section{ACKNOWLEDGEMENTS}

The authors would like to thank Mustansiriyah University-Baghdad-Iraq for its support in the present work. We would also like to thank Mr. Ali Abdulhussein and Mr. Hamza for their help.

\section{REFERENCES}

Abbas, A.A.A. and Hassan, F.M. 2017. Water quality assessment of Euphrates river in Qadisiyah province (Diwaniyah river), Iraq. Iraqi J. Agric. Sci., 48(6).

Abdel-Ghani, N.T. and Elchaghaby, G.A. 2007. Influence of operating conditions on the removal of $\mathrm{Cu}, \mathrm{Zn}, \mathrm{Cd}$ and $\mathrm{Pb}$ ions from wastewater by adsorption. International Journal of Environmental Science \& Technology, 4: 451-456.

Akcay, H., Oguz, A. and Karapire, C. 2003. Study of heavy metal pollution and speciation in Buyak Menderes and Gediz river sediments. Water Res., 37: 813-22.

Al-Ani, R.R., Al Obaidy, A.M.J. and Hassan, F.M. 2019. Multivariate analysis for evaluation of the water quality of Tigris River within Baghdad city in Iraq. Iraqi J. Agric. Sci., 50: 331-42.

Al-Ansari, N. 2013. Management of water resources in Iraq: Perspectives and prognoses. Engineering, 5: 667-84.

Al-Dulaimi, G. A. and Younes, M. K. 2017. Assessment of potable water quality in Baghdad City, Iraq. Air, Soil and Water Research, 10: 1178622117733441.

Al-Obaidi, A.H. 2009. Evaluation of Tigris river quality in Baghdad for the period between (November 2005-October 2006). Engineering and Technology Journal, 27(9): 1736-1745.

Alobaidy, A.H.M.J., Maulood, B.K. and Kadhem, A.J. 2010. Evaluating raw and treated water quality of Tigris River within Baghdad by index analysis. J. Water Resour. Prot., 2: 629.

Bain, R., Cronk, R., Wright, J., Yang, H., Slaymaker, T. and Bartra, M, J. 2014. Fecal contamination of drinking-water in low- and middle-income countries: a systematic review and meta-analysis. PLoS Med, 11: e1001644.
Chagas, T.P., Seki, L.M., Cury, J.C., Oliveira, J.A., Davila, A.M., Silva, D.M. and Asensi, M.D. 2011. Multi resistance, beta-lactamase-encoding genes and bacterial diversity in hospital wastewater in Rio de Janeiro, Brazil. J. Appl. Microbiol., 111: 572-81.

Davies, J. and Davies, D. 2010. Origins and evolution of antibiotic resistance. Microbiol. Mol. Biol. Rev., 74: 417-33.

GadzalLa-Kopciuch, R.B.B., Bartoszewicz, J. and Buszewski, B. 2004. Some considerations about bioindicators in environmental monitoring. Pol. J. Environ. Stud., 13: 453-62.

Gangwar, R.K.K.P., Singh, J. and Singh, A.P. 2012. Assessment of physico-chemical properties of water: River Ramganga at Bareilly, UP. J. Chem. Pharm. Res., 4: 4231-4.

Harnisz, M. 2013. Total resistance of native bacteria as an indicator of changes in the water environment. Environ. Pollut., 174: 85-92.

Hassan, F.M. and Mahmood, A.R. 2018. Evaluate the efficiency of drinking water treatment plants in Baghdad City-Iraq. J. Appl. Env. Microbiol., 6: $1-9$.

Hassan, F.M., 2004. Limnological features Diwanyia River, Iraq. Baghdad Science Journal, 1(1): 119-124.

Ibrahim, I.A. and Asmaa, S.A.K. 2017. The relation between bacterial and heavy metal water pollution and blood micronuclei as biomarkers in the Tigris river fish. Baghdad Sci. J., 14: 126-134.

Icgen, B. and Yilmaz, F. 2014. Co-occurrence of antibiotic and heavy metal resistance in Kizilirmak River isolates. Bull. Environ. Contam. Toxicol., 93: 735-43.

Korzeniewska, E. 2011. Emission of bacteria and fungi in the air from wastewater treatment plants - A review. Front Biosci. (Schol Ed.), 3: 393-407.

Le Corre, K.S., Ort, C., Kateley, D., Allen, B., Escher, B.I. and Keller, J. 2012. Consumption-based approach for assessing the contribution of hospitals towards the load of pharmaceutical residues in municipal wastewater. Environ. Int., 45: 99-111.

Leung, H. W., Minh, T. B., Murphy, M. B., Lam, J. C., So, M. K., Martin, M., Lam, P. K. and Richardson, B.J. 2012. Distribution, fate and risk assessment of antibiotics in sewage treatment plants in Hong Kong, South China. Environ. Int., 42: 1-9.

Lv, L., Yu, X., Xu, Q. and Ye, C. 2015. Induction of bacterial antibiotic resistance by mutagenic halogenated nitrogenous disinfection byproducts. Environ. Pollut., 205: 291-298.

Mahmood, A. R., Al-Haideri, H. H. and Hassan, F. M. 2019. Detection of antibiotics in drinking water treatment plants in Baghdad City, Iraq. Advances in Public Health, 2019: 10.

Michael, I., Rizzo, L., Mcardell, C. S., Manaia, C. M., Merlin, C., Schwartz, T., Dagot, C. and Fatta-Kassinos, D. 2013. Urban wastewater treatment plants as hotspots for the release of antibiotics in the environment: a review. Water Res., 47: 957-95.

Nicolau, R., Galera-Cunha, A. and Lucas, Y. 2006. Transfer of nutrients and labile metals from the continent to the sea by a small Mediterranean river. Chemosphere, 63: 469-76.

Nouri, J., Lorestani, B., Yousefi, N., Khorasani, N., Hasani, A.H., Seif, F. and Cheraghi, M. 2011. Phytoremediation potential of native plants grown in the vicinity of Ahangaran lead-zinc mine (Hamedan, Iran). Environ Earth Sci., 1(62): 639-644.

Obaidy, A.M.J., Talib, A.H. and Zaki, S.R. 2014. Environmental assessment of heavy metal distribution in sediments of Tigris River within Baghdad City. International Journal of Advanced Research, 2(8): 947-952.

Robertson, D. M., Saad, D. A. and Heisey, D. M. 2006. A regional classification scheme for estimating reference water quality in streams using land-use-adjusted spatial regression-tree analysis. Environ. Manage., 37: 209-29.

Sin, S. N., Chua, H., Lo, W. and Ng, L. M. 2001. Assessment of heavy metal cations in sediments of Shing Mun River, Hong Kong. Environ. Int., 26: 297-301. 
Smith, R. 2004. Current Methods in Aquatic Science. University of Waterloo, Canada.

Srebotnjak, T., Carr, G., Sherbinin, A. D. and Rickwood, C. 2012. A global water quality index and hot-deck imputation of missing data. Ecological Indicators, 17: 108-119.

Stark Jr, H.P., Goldstein, R.M., Fallon, J.D., Fong, Al, Lee Ke, Et Al. [Internet]. Reston, Va: U.S. Geological Survey. 2000. Water quality in upper Mississippi River basin, Minnesota, Wisconsin, South Dakota, Iowa, and North Dakota, 1995-98 [Online]. Available: http://pubs.er.usgs. gov/publication/cir1211.

Su, S.X.R., Mi, X., Xu, X., Zhang, Z. and Wu, J. 2013. Spatial determinants of hazardous chemicals in surface water of Qiantang River, China. Ecol Indic, 1: 375-81.

Titilawo, Y., Obi, L. and Okoh, A. 2015. Antimicrobial resistance determinants of Escherichia coli isolates recovered from some rivers in Osun State, South-Western Nigeria: Implications for public health. Sci. Total Environ., 523: 82-94.

Wayne, P., 2014. Clinical and Laboratory Standards Institute: Performance standards for antimicrobial susceptibility testing: Twenty-fourth informational supplement, M100-S24. Clinical and Laboratory Standards Institute (CLSI), 34(1).
Wickham, J.D., R.K., Wade, T.G. and Jones, K.B. 2005. Evaluating the relative roles of ecological regions and land-cover composition for guiding establishment of nutrient criteria. Landsc. Ecol., 1(20): 791-798.

Xu, Y.B., Hou, M.Y., Li, Y.F., Huang, L., Ruan, J.J., Zheng, L., Qiao, Q.X. and Du, Q.P. 2017. Distribution of tetracycline resistance genes and $\mathrm{AmpC}$ beta-lactamase genes in representative non-urban sewage plants and correlations with treatment processes and heavy metals. Chemosphere, 170: 274-281.

Yuan, G.L., Liu, C., Chen, L. and Yang, Z. 2011. Inputting history of heavy metals into the inland lake recorded in sediment profiles: Poyang Lake in China. J. Hazard Mater., 185: 336-45.

Zarfel, G., Galler, H., Feierl, G., Haas, D., Kittinger, C., Leitner, E., Grisold, A. J., Mascher, F., Posch, J., Pertschy, B., Marth, E. and Reinthaler, F.F. 2013. Comparison of extended-spectrum-beta-lactamase (ESBL) carrying Escherichia coli from sewage sludge and human urinary tract infection. Environ. Pollut., 173: 192-9.

Zhang, S., Han, B., Gu, J., Wang, C., Wang, P., Ma, Y., Cao, J. and He, Z. 2015. Fate of antibiotic resistant cultivable heterotrophic bacteria and antibiotic resistance genes in wastewater treatment processes. Chemosphere, 135: 138-45. 